\title{
Hispanism and the historiography of colonial Latin America: North American trends
}

\section{El hispanismo y la historiografía de América Latina colonial: tendencias norteamericanas}

Kris LANE

Tulane University

klane1@tulane.edu

Fecha de recepción: 16-11-2019

Fecha de aceptación: 20-02-2020

\section{RESUMEN}

El hispanismo o la fascinación por todo lo "español" tienen una larga tradición en los Estados Unidos. El fenómeno ha tenido tanto manifestaciones populares como académicas, y por lo tanto debe tratarse de una manera amplia cuando se tiene en cuenta la historiografía de la América Latina colonial producida por académicos anglófonos, tanto dentro como fuera de los EE. UU. Los apologistas, críticos y todos los demás han tenido que lidiar con el legado hispano en las Américas, tanto en lo cultural como en lo religioso, económico, ambiental y de otro tipo. Este ensayo rastrea las principales preocupaciones o preguntas "hispanas" que generaron subcampos académicos y escuelas durante el último cuarto de siglo más o menos entre los anglófonos que investigan sobre América Latina colonial. La pregunta sigue siendo: ¿En qué medida el hispanismo o la preocupación por los múltiples legados coloniales de España han impulsado estas tendencias historiográficas? ¿Se ha desvanecido el hispanismo o simplemente ha tomado nuevas formas?

Palabras clave: Historiografía, Hispanismo, Hispanismo norteamericano Topónimos: América Latina colonial

Período: siglo XX

\section{ABSTRACT}

Hispanism or the fascination with all things "Spanish" has a long history in the United States. The phenomenon has had both popular and scholarly manifestations, and thus must be treated broadly when reckoning with the historiography of colonial Latin America produced by Anglophone scholars, both inside and outside the U.S. Apologists, critics, and everyone in between have had to grapple with the Hispanic legacy in the Americas: cultural, religious, economic, environmental, and otherwise. This essay traces the main "Hispanic" concerns or questions that spawned scholarly subfields and schools over the last quarter-century or so among Anglophones working on colonial Latin America. The question remains: to what degree was Hispanism or a concern with Spain's multiple colonial legacies a driver of these historiographical trends? Has Hispanism faded from view or has it simply taken on new guises? 
Key words: Historiography, Hispanism, North American Hispanism

Place names: Colonial Latin America

Period: XXth century

\section{INTRODUCTION}

What does Hispanism have to do with colonial Latin America? As it turns out, quite a lot, but with caveats. As Richard Kagan has brilliantly shown in The Spanish Craze (2019), North American Hispanism has long been associated with Hispanophilia, which in the United States has alternated since the early days of the republic with Hispanophobia. This lovehate approach to all things Hispanic has shaped both scholarly and popular culture for two centuries, sometimes entangled with the plight of immigrants. It has also been influenced by the shifting role of the Catholic Church in the U.S., which remains (like Canada) a largely Protestant nation. Another specter hovering over Hispanist or "Hispanic Americanist" scholars in all English-speaking nations is the tangled legacy of British-Spanish relations since the reign of Henry VIII.

"Spanish crazes" in the United States often occurred between wars, as in the 1920s when Hispanic Revival architecture was all the rage from Coral Gables, Florida, to Santa Barbara, California. Every borderland city of note needed at least one knock-off of Seville's Giralda. A more troubled Hispanism appeared in the years surrounding the Columbus quincentennary in 1992, a time of soul searching epitomized by the title Colonial Legacies: The Problem of Persistence in Latin American History (Adelman, 1999). The quincentennary nearly coincided with the formal end of the Cold War, prompting still more reflection. Was a Hispanic colonial heritage something to be proud of or something to shake off or overcome? Was Spanish colonialism really the source of postcolonial economic burdens or shortcomings? Would Hispanic legacies now be treated differently by scholars of, say, Mexico, versus scholars of Bolivia or the Dominican Republic? What about scholars of the U.S. South and Southwest? Would U.S. History be re-written from the "Hispanic margins"? And in the case of colonial Latin America, would the histories of women, indigenous peoples, enslaved Africans or Filipinos, religious minorities, and the so-called castas finally mature to challenge stock narratives?

Scholars of colonial Latin America have hived off into various subgroups, several of which can hardly be called Hispanist —indeed, some ethnohistorians could almost be called anti-Hispanist (although as I will argue below, this is debatable). In any case, most historians of colonial Latin America in the Anglophone world today share a Hispanist genealogy. Nearly all of the scholars mentioned below worked (and still work) in Spanish archives at least part time, and in the classroom most of them expend considerable energy "explaining Spain" before trying to explain Spanish colonialism and the varied struggles against it in the Americas. Explanation is not apology, leaving Anglophone scholars to squirm as they try to situate Hispanic colonialism under the harsh light of postcolonial discourse (Mignolo 1995).

There is a strong and equally complex Hispanist legacy in U.S. literary studies related to colonial Spanish America, and the strength of Spanish language programs and departments in the U.S. as of this writing is the envy of all other foreign language specialists. To some degree the recent popularity of Spanish in U.S. education has enabled a broadening of "Hispanic (American) Cultural Studies" into areas once claimed by the field of history (Cruz, 2008). These include the history of science and technology (Bauer, 2019; Bentancor, 2017; Bigelow, 2020) and the history of piracy (Firbas, 2006; Marrero-Fente, 2017; McCarl, 2011), but these shifts may be seen as partial outgrowths of an earlier trend away from 
post-structuralism toward "historicism", in part focused on analyzing both canonical and non-canonical texts within their historical contexts (Adorno, 1986, 1999, 2007, 2015). It is increasingly common to encounter literary historians in the archives.

Colonial Latin American art historians have their own "Hispanist" stories to tell, as do historians of music, theatre, and dance. This essay can only gesture to the significant growth of these areas of "colonial Hispanic study" in recent decades. Highly influential fieldcrossing works have multiplied, often challenging canonical or "great man" approaches to embrace indigenous and other non-European perspectives and the ambivalence of colonial situations. Colonial art history has come a long way since the days of George Kubler (Mundy and Hyman, 2019; Boone and Mignolo, 1994; Cohen-Suárez, 2016; Dean, 1999; DonahueWallace, 2016; Katzew, 2004, 2011; Leibsohn, 2009, 2012; Mundy, 1996, 2015; Solari 2013, 2019; Webster, 2017).

And then there is Spanish hispanismo, studied by U.S. scholar Frederick Pike (1971) and more recently by the late Christopher Schmidt-Nowara $(2006,2008)$. This variant, more properly hispanoamericanismo, was comparable to the British notion of post-imperial commonwealth nations, which linked newly free ex-colonies to the former colonizer by language, culture, and law. This hispanismo surged with the dissolution of the Spanish empire in America and the Philippines after 1898, emblematized perhaps by the 1929 IberoAmerican Exposition in Seville. For early Latin Americanists in the U.S., hispanismo as soft imperial power was familiar, a form of nostalgia akin to Anglophilia, whereas for Latin American intellectuals it was an existential threat to new nationalist paradigms which almost by definition demanded rejection of all things "Spanish". The plight of José Rizal embodied this struggle in the Philippines (Anderson 2005).

What follows is an attempt to trace major trends in the field of colonial Latin American history as related to the "Hispanist impulse" or interest in Hispanic legacies while also sorting and labeling methodological variations and schools of thought. As for regional coverage, it will quickly become evident that U.S., Canadian, and other Anglophone scholars have concentrated overwhelmingly on the history of Mexico, or New Spain. Geographical proximity helps explain this focus in North America, and Mexico's demographic weight is not inconsiderable. One might even speak of "Novohispanismo".

Historians of the Spanish Caribbean and Central America might vie for second place in the larger field of colonial Latin American history by volume, followed by scholars of Greater Peru, the Southern Cone, and the northern Andes. More Anglophone work on these relatively neglected regions is appearing all the time, but the proportions remain roughly the same as they were fifty years ago. In all cases, Anglophone historians rely heavily on the prodigious and innovative work of Latin American and Spanish scholars (to say nothing of other nationalities). This essay cannot begin to assess this massive body of Hispanophone work nor trace its braided historiographical streams.

The historiography of the so-called U.S. Hispanic Borderlands has grown as well, although its relationship to colonial Latin American historiography remains tenuous or runs parallel, pulled in other directions by the tremendous gravity of U.S. history or historiography. To save space, this article stays "south of the border", tracing "Hispanic-American" sub-themes that have persisted or sprung up in the last few generations, among them: economy, bureaucracy, conquest, cultural expression, environment, ethnohistory, frontiers, demography, gender and women's history, law, labor, race, religion, science and medicine, sexuality, slavery and the slave trade, and transatlantic and even global approaches to the broader Hispanic world. The list of themes continues to grow, but most of the scholars listed can trace genealogies to early North American hispanists. 


\section{ECONOMIC AND ENVIRONMENTAL HISTORY}

Stanley J. Stein (1920-) made his name with Vassouras (1957), a rich study of slavery and environmental degradation on coffee plantations in nineteenth-century Brazil. Stein later turned to eighteenth-century Spain and its empire along with his wife Barbara $\mathrm{H}$. Stein, a bibliographer. Together they published a thorough and incisive trilogy on the rise and fall of the Bourbon revival project (Silver, Trade, \& War; Apogee of Empire; and Edge of Crisis). The seed for this work germinated for some time, as the Steins had published a highly popular essay collection in 1970: The Colonial Heritage of Latin America, regarded by some as a defense of dependency theory. The later trilogy served as "proof' of the Steins" theorem: Spain found inestimable riches in the Americas only to shoot itself in the head with a silver bullet.

One historian who has carried on in the tradition of the Steins is Jeremy Baskes. In 2000, Baskes offered a radically revised history of the repartimiento de mercancías or sale of surplus goods by royal officials in southern Mexico, and in 2013 he explored much broader horizons in Staying Afloat: Trade and Uncertainty in Spanish Atlantic World Trade, 1760-1820. In a similar mode is Robert Patch's study Indians and the Political Economy of Colonial Central America, 1670-1810 (2013), in part a sequel to the foundational work of Murdo Macleod. Louisa Schell Hoberman, a student of James Lockhart at UCLA, produced a rich study of Mexico City's merchant elite (1991) and also co-edited two volumes on city (1986) and countryside (1996) in colonial Latin America.

There is no great "school" of new economic history in colonial Spanish America in the U.S. as of this writing, but scholars trained at Emory University under Susan Socolow, including Fabricio Prado and Alex Borucki, are expanding our understanding of merchant communities, smugglers, and slavers in the Río de la Plata. Ernesto Bassi, Jesse Cromwell, and Edward Pompeian have followed similar leads in their studies of late-colonial Caribbean trade. Traders often jumped out of the "Hispanic" box, but they were always entangled in the imperial webs spun by crown and consulado.

The reader will have noticed that the historians treated thus far have not been characterized in terms of their theoretical affinities. Perhaps a distinctive feature of the history profession in the U.S. and to a lesser extent, Canada has been a general shyness toward theory, or to exposing one's preferences or influences. Among the few U.S.-based economic historians of colonial Latin America to openly embrace a Marxist-inspired framework is John Tutino, whose Making a New World (2011) argues that modern capitalism's origins should be traced to eighteenth-century Mexico rather than to eighteenth-century Great Britain. New Spain's famed ranching-mining-trade complex was of such scale and value as to make early English factories appear puny. Making a New World book signals a return to a reckoning with historical materialism, as seen in much recent work on the antebellum U.S. South.

Economic historian John J. TePaske's work ranged widely, including a psychological study of Philip II, but he is best known for his statistical studies of Spain's royal treasury, often compiled in conjunction with Herbert Klein. This work remains standard, with minor modifications. Klein is still actively publishing major studies of Bolivian, Brazilian, and Cuban economic history in addition to works the history of slavery and the slave trade. A demographic historian as well, Klein has examined the long history of Hispanics in the U.S. (2009). Klein is, along with John Coatsworth, one of the great "big picture" historians of political economy and demography, not just for Latin America, but for the hemisphere.

Several of TePaske's students took his lead in economic matters to deepen our understanding of colonial Peru. Kendall Brown examined the brandy industry in eighteenthcentury Arequipa before turning to the mercury mines of Huancavelica. Brown's History of Mining in Latin America (2012) is a superb synthesis as well as a commentary on the 
previously unrecognized environmental costs of extraction. Kenneth Andrien, another TePaske student, made his mark on the history of seventeenth-century Peru with Crisis and Decline (1985) before turning to the aborted revival of eighteenth-century Quito (1996). Andrien's understanding of colonial finances and bureaucracy is matchless, and he has since turned to the early Bourbon reforms, publishing, with Allan Kuethe, The Spanish Atlantic World in the Eighteenth Century (2014). A new trend in scholarship is a hard look at the early Bourbons (see, for example Frances Ramos, Adrian Pearce, and Christoph Rosenmüller).

Another TePaske student, Jane Mangan, took her mentor's interest in economy to the informal sector of colonial Potosí, focusing mostly on the seventeenth century. Mangan's breakthrough Trading Roles (2005) demonstrated how notary records could reveal a hidden women's world of trade and sociability. Mangan's work joined a growing chorus of studies on women in the colonial economy. Kathryn Burns, in Colonial Habits (1999), took a page from Asunción Lavrin (discussed below) to show how the convents of early colonial Cuzco served as major lending institutions, and Karen Graubart traced the market activities of women in Trujillo, Lima, and other Peruvian towns (2007). Kimberly Gauderman, a student of James Lockhart, produced a similar study of Quito's market women (2003), also challenging prevailing claims of patriarchal control in the colonial Hispanic world more broadly. Gauderman's student Chad Thomas Black carried this project forward in his examination of eighteenth-century Quito and women's prominent place in the economy (2012). Taken together, this and related work by scholars such as Sonia Lipsett-Rivera on Mexico has challenged received wisdom with regard to "Hispanic patriarchy", both as a legal phenomenon and as socio-economic reality.

Mining history has been something of a subfield among historians of colonial Latin America, branching out in recent years beyond the core themes of overall productivity and labor. In addition to Kendall Brown and geographer Robert C. West, historians of colonial Spanish American mining have included Peter J. Bakewell, David Brading, Harry Cross, Richard Garner, Jeffrey Cole, and Alan Craig. Bakewell's work has been most wide-ranging, from Zacatecas to Potosí. Dana Velasco Murillo (University of California, San Diego) has revived interest in Mexico's northern mining towns (2016), prompting what some are calling New Mining History. This history highlights the contributions of women, native peoples, and enslaved and free workers - and occasionally mine owners - of African descent. Literary scholars have added to the mix, extracting and examining root metaphors from mining texts and other "Hispanic" writings. At the cutting edge of this work are Ralph Bauer, Orlando Bentancor, and Allison Bigelow.

Canadian historian Daviken Studnicki-Gizbert and several of his students have pioneered a new environmental history of colonial mining, focused mostly on Mexico. Studnicki-Gizbert studied under Stuart Schwartz, whose work is discussed below. Laurent Corbeil has followed in the vein of Velasco Murillo in tracing indigenous migration to the silver and gold town of San Luis Potosí and Saúl Guerrero, in Silver by Fire, Silver by Mercury (2017) has forced a total reconsideration of the notorious amalgamation process and its environmental consequences. Guerrero, a Venezuela-born chemist, explains how much smelting mattered alongside amalgamation (an insight noted earlier by economic historian Richard Garner). Guerrero plots in detail how destructive and contaminating all forms of silver mining and refining were in the colonial and early national periods. In dialogue with Guerrero's work is Nicholas Robins' study of Potosí and Huancavelica, Mercury, Mining, and Empire (2011) and (on Huancavelica only) Santa Barbara's Legacy (2017).

Not all that glittered in Spanish America was silver —or even quicksilver. Sherwin Bryant, in Rivers of Gold, Lives of Bondage (2014), has taken up the study of Colombian gold mining last treated in depth (in English, at least) by Frederick Sharp in 1976. In addition 
to work on the goldfields of early Ecuador and Colombia, the present author (Kris Lane) has explored the early modern emerald business in Colombia and the world in Colour of Paradise (2010). Molly Warsh has revived interest in colonial Caribbean pearl fishing in American Baroque (2018). This, like the work of Bauer, Bentancor, and Bigelow, is in line with the new History of Science and Technology discussed further below. Also in this vein is Elvira Vilches, whose book New World Gold (2010) takes us back to the curse of treasure on Spain itself, a topic explored by economic historians Regina Grafe, Alejandra Irigoin, and others.

Environmental history is on the rise. Stuart B. Schwartz, best known for his work on colonial Brazil, produced a magisterial history of Caribbean hurricanes (2015) that goes a long way toward rehabilitating Hispanic American science. Andeanist Charles Walker offered a fresh take on natural disaster with Shaky Colonialism (2008), an environmental and social history of the 1746 Lima earthquake. Argentine-born historian Vera Candiani has revived the lessons of the so-called Berkeley School (where she was trained) in Dreaming of Dry Land (2014). This deeply researched study of the colonial draining of central Mexico's great lakes is a model for environmental historians. Candiani points to clashing modes of water management and urbanization, essentially pitting the Spanish colonizers against nature in a centuries' long battle to build Mexico City. "Hispanism", in this case, was misguided.

The problem of water management in colonial central Mexico has drawn other Anglophone scholars. Bradley Skopyk and Richard Conway are in different ways challenging the assumption that "Hispanic" intrusion was simply catastrophic. Skopyk, trained by pioneer environmental historian Elinore Melville at York University in Canada (her 1994 book A Plague of Sheep set a high bar for the field), incorporates an extraordinary amount of new data on the so-called Little Ice Age to argue that some factors beyond human control deeply affected the colonial environment of central Mexico (2020). Taking a more cultural and ethnohistorical angle, incorporating indigenous-language documents, Conway (in press) asks how environmental change in the lacustrine Mexico City suburb of Xochimilco looked from indigenous perspectives across the entire colonial period. How important were 'Hispanic' land use patterns here?

\section{TRANSATLANTIC TIES}

Hispanic and Latin American Studies in the U.S. has always been in touch with if not always aligned with trends in the U.K. A pioneer who is thankfully still writing is John $\mathrm{H}$. Elliott, who has done much to bridge the Atlantic in his own work and in training students. Elliott's 2006 Empires of the Atlantic World continues to spark debate and further research. A Hispanist to the core, Elliott also continues to push historians of North America and the British Caribbean to broaden their horizons in order to see more clearly the different but shared legacies of overseas colonialism.

A contemporary or precursor of sorts was John H. Parry (1914-1982), who began studying colonial bureaucracy in Mexico but whose interests soon spanned Spain's global maritime empire, which Parry compared with those of Portugal, the Netherlands, France, and Great Britain. This is not the place to attempt an exhaustive list, but among the many British historians and geographers of colonial Latin America who have influenced U.S. scholarly trends one must count Kenneth Andrews, David Brading, Peter Bradley, Rebecca Earle, John Hemming, Anthony McFarlane, and Linda Newson. Newson, a historical geographer based in London, has probably ranged more widely than any of her peers, producing an extraordinary series of monographs on population history, medicine, the slave trade, and much more from Trinidad to Honduras to Nicaragua to Ecuador to Guinea-Bissau to the Philippines. 
Among the British scholars of Latin America who have mostly taught in the U.S. or Canada, one must count Peter J. Bakewell, Susan Deans-Smith, George Lovell, the late Elinor Melville, Murdo MacLeod, and David J. Robinson. A geographer, Robinson has produced numerous works of colonial Latin American history. Like Newson, Robinson has ranged all over Latin America, from Mexico to the Southern Cone. His work has included population history, migration studies, and much more, capped by serial publication of numerous primary sources for the early history of Peru.

But by "Transatlantic Ties" we mean something else as well: histories of what some now call the Hispanic Atlantic. Pioneers in this sub-field include Carla Rahn Phillips and her husband William D. Phillips, a specialist on medieval Spain. After a first book on early modern Ciudad Real, C. R. Phillips produced numerous books on Spain's maritime history, most notably Six Galleons for the King of Spain (1986) and The Treasure of the San José (2007). Together, the couple published a nuanced study of Columbus just in time for the 1992 quincentennary. C. R. Phillips also translated Spanish historian Pablo Pérez-Mallaína's pathbreaking Spain's Men of the Sea for anglophone audiences. Interest in Columbus persists, and Nicolás Wey-Gómez, has provided the most comprehensive revision, mostly in the vein of the history of science (2008).

Ida Altman bridged Spanish and Spanish-American history in ways not attempted before. In two books, Emigrants and Society (1989) and Transatlantic Ties (2000), Altman showed how families in distinct parts of Spain practiced chain migration (and return migration) over several centuries. Altman has since published a study of Mexico's Mixtón War (2010) plus a body of articles and a collected volume on the earliest Spanish experience in the Caribbean. Another pioneering transatlantic history was Noble David Cook and Alexandra Parma Cook's Good Faith and Truthful Ignorance (1991), which used Inquisition records to trace transatlantic "Hispanic" lives through bigamy.

In a similar vein, Juan Javier Pescador traced Peninsular migrants to America along with returnees in The New World Inside a Basque Village (2003). Like Altman's books, Pescador's study was more interested in how regional Iberian identities or ties were maintained across generations. Put another way, these works are less "Hispanist" than might be imagined given early modern concepts of belonging. They talk to the durability of the patria chica. Edith Couturier pursued something similar but in a biographical mode in The Silver King (2005), a study in wealth and power focused on the Andalusian merchant who became Mexico's Count of Regla. This followed in some ways Peter J. Bakewell's 1987 biographical study of Potosí silver magnate Antonio López de Quiroga, a Galician mining entrepreneur and one of the richest men of the seventeenth century Americas.

More recently, Jane Mangan has followed a similar family story, or set of stories, in Transatlantic Obligations (2015) exploring the meaning (or at times unimportance) of mestizaje at the most intimate level. Not all migrants were Europeans or Africans, and in the provocatively titled Global Indios: The Indigenous Struggle for Justice in the Sixteenth Century (2015), Canadian scholar Nancy van Deusen follows a number of native Americans who ended up in Spain soon after conquest, explaining their peculiar dilemmas in a world of moriscos, conversos, Gypsies, enslaved Africans, and other "suspect" minorities.

By contrast, Karoline Cook in Forbidden Passages (2016) follows the fate of moriscos who made it to the Indies in the same period, mostly against royal policy. Leo Garofolo has followed a similar line of inquiry in tracing the lives of Africans and their descendants in a mixed, transatlantic and transpacific Hispanic world. Some enslaved Africans spent time in Peru or Mexico or even the Philippines before landing in Spain, the Canary Islands, and Italy. Tatiana Seijas' landmark book Asian Slaves in Colonial Mexico (2014) illuminates a huge transpacific Hispanic world in which captives from as far away as Goa were forced to labor in New Spain. 
For the seventeenth century, Sarah Owens has built on her work on Spanish nuns to trace their global peregrinations. In Nuns Navigating the Spanish Empire (2017) and other works, Owens uses the nuns' own writings, some of them still housed in a Toledo convent, as the basis for the story. Moving to the eighteenth century, Allyson Poska, trained by Carla Rahn Phillips and Stuart Schwartz as a historian of early modern Spain, has followed a number of Galician immigrants as they attempted to colonize the south coast of Argentina in the late Bourbon period. Gendered Crossings (2016) is an outstanding work in many respects, not least being its focus on women as the key to any successful colonial enterprise.

Another ocean-hopper has been Tamar Herzog, who began by studying elite bureaucratic culture in Quito (1995) and moved to much broader canvasses including citizenship and subjecthood (2003) and imperial frontiers (2015). Herzog, trained in France, has been among the first U.S.-based scholars to work intensively on what may be called the new history of empires, centered in Lisbon, Madrid, Florence, and Frankfurt. This revisionist scholarship has yet to get a firm hold in the U.S., but historians such as Gabriel Paquette and Christoph Rosenmüller are beginning to change this. Rosenmüller's book Corruption and Justice in Colonial Mexico, 1650-1755 (2019) is the most thorough examination of colonial corruption to date, informed not only by Spanish and Mexican sources but also by archival materials housed in the Habsburg court in Vienna.

What many of the above works share is an abiding interest in the connectedness of early modern Spain and its overseas possessions or claims. As J. H. Elliott has long argued, one can scarcely understand colonial societies without at least a short course on the colonizing country. Beyond this, the above works are beginning to show how "the colonized" came home, and how they often changed or shaped the very thing becoming known as Spain. Colonialism was a two-way process, even as the so-called colonies grew apart, forming new and arguably less "Hispanic" identities. This raises the question of how to reconcile old-fashioned Hispanism and what is nowadays called ethnohistory, or the history of indigenous peoples under colonialism.

\section{THE NEW PHILOLOGY AND OTHER POST-COLD WAR TRENDS}

A major historiographical trend that began in the 1980s but only matured and flourished after about 1990 was the pursuit of indigenous history by way of native-language documents. Dubbed "The New Philology" by James Lockhart, its guiding force at UCLA, this "school" focused on training researchers from several disciplines but mostly historians in the decipherment of Nahuatl, Ñudzahui, Yucatec Maya, and other native-language manuscript records. Most of these documents were found in what is today Mexico and Guatemala, where local scribes kept town council books, notarized bills of sale, wills, and so on. Some even wrote full-fledged chronicles in their native languages. There were also dictionaries, grammars, confessional manuals, and other Spanish-produced items to consult. The Florentine Codex, first translated by U.S. scholars Charles Dibble and Arthur Anderson beginning in the 1950s, had already come to serve as a kind of Rosetta Stone.

The New Philology was a clear departure from prevailing colonial Latin American "Hispanism", and at first glance it may seem a wholesale rejection of Hispanism. Lockhart, who had published acclaimed social history studies such as Spanish Peru (1968) and The Men of Cajamarca (1972) —both decidedly "Hispanist" works in both argument and content_ was convinced that this new philological approach required shedding everything one had learned in order to adopt truly indigenous perspectives, or at least to get close to them. Devotees had to all-but block out the Spanish and Spanish American record, otherwise indigenous perspectives might be lost, overshadowed, or contaminated. Lockhart's synthetic Nahuas After the Conquest (1992) was both counterpoint to and expansion of Charles Gibson's landmark 1964 Aztecs under Spanish Rule. It was also seen as a new beginning. 
Lockhart trained many students at UCLA, and they soon filled posts in colonial Latin American history across the U.S. Kevin Terraciano took over at UCLA, focusing on the Mixteca Alta, which boasts a rich cache of Ñudzahui or "Zapotec" documents. Matthew Restall focused on the Yucatec Maya, who also carried on writing in their language throughout the colonial period. Restall has carried the tradition of New Philology forward at the Pennsylvania State University, training students such as Mark Z. Christensen (BYU) and also introducing a "New Conquest History" that examines non-Spanish participation in the Americas' many conquest campaigns. This history challenges the notion of conquest as a simple "Hispanic" enterprise, emphasizing indigenous aims and accomplishments.

Other Lockhart students who developed or drew energy from the New Philology include Sarah Cline, Stephanie Wood and Robert Haskett, Susan Schroeder, Lisa Sousa, Pete Sigal, Robinson Herrera, Caterina Pizzigoni, and Camilla Townsend. Townsend has done much to synthesize and explain the gains made by the New Philologists over the last four decades. Her prize-winning Annals of Native America (2016) is a fluid examination of indigenous historians in colonial Mexico, and her book Fifth Sun (2019) offers a new perspective on the so-called Aztecs before and after the arrival of the Spanish. It may seem that "Hispanism" is eclipsed in these works in favor of "purely" indigenous perspectives, but I would urge caution, as the emerging story is not simply the other side of a known coin.

Mesoamerican ethnohistory is as messy and contradictory as any history that came before it. Laura Matthew, a student of Nancy Farriss at the University of Pennsylvania, has taken a page from the New Conquest History in her studies of Nahua colonization in Guatemala (2012), a topic also explored by Florine Asselbergs and Matthew Restall. Sean McEnroe, who trained under William B. Taylor at Berkeley, has traced Tlaxcalan auxiliaries and colonists in Mexico's far north (2014). Working in the vicinity of Oaxaca, Yanna Yannakakis, another student of Nancy Farriss, has revealed a complex social milieu in which go-betweens and legal experts mitigated some of colonialism's worst abuses. Like Bryan Owensby, Yannakakis has done much to develop our understanding of indigenous legal history in the wake of Woodrow Borah's Justice by Insurance. To boot, the second and third generations of New Philologists are expanding the field even further, among them Amber Brian (2016), Peter Villella (2016), and Bradley Benton (2017). Notably, these three scholars have focused on indigenous elites caught between worlds.

This turn to indigenous elites and their "conquests" raises the question: Is New Philology really a break from Hispanism, or is it an inversion (or something else)? Certainly the search for indigenous perspectives takes us deep into non-Western territory and this is the main thrill and challenge, yet as Lockhart himself noted years ago, the New Philology also traces the long and tortured process of native American peoples becoming Spanish subjects. Surviving records may be in Nahuatl or Ñudzahui, but their contents are quite familiar to students working in Spanish-language documents, even in Spain. Indigenous elite writings, in particular, expose a hybrid world in which Spanish colonial rule is a given, something to be worked with, complained about, and reformed. Many New Philologists may disagree, but one could interpret Lockhart's phases of linguistic change in central Mexico as creeping Hispanization.

\section{ANDEAN ETHNOHISTORY}

Scholars of the Andes, working with far fewer indigenous-language documents, turned to ethnography for inspiration and access to native mentalities while still focusing on colonial archival records. The anthropologist John V. Murra was a major influence on ethnohistorians as was Nicolás Sánchez-Albornoz, focused more on population trends. In Peru, Noble David Cook followed both the ethnohistorical and indigenous demographic history veins, as did Ann Wightman in greater Cuzco and Ann Zulawski in central and southern Bolivia. 
Karen Spalding took a materialist micro-regional approach in Huarochirí (1984) as did Steve Stern in his very popular Peru's Indian Peoples and the Challenge of Spanish Conquest (1982), focused on Huamanga (Ayacucho). Stern's many students include Rachel Sarah O'Toole, Sinclair Thomson, Ana Schaposchnik, Leo Garofolo, James Krippner, Cynthia Milton, and the late Douglas Cope. Thomson followed Stern in his early interest in Andean rebellions and indigenous agency more broadly in his study of Bolivian peasant rebellion, We Alone Will Rule (2002).

Also working in Bolivia was the late anthropologist Thomas A. Abercrombie, whose monumental Pathways of Memory and Power (1998) blended fieldwork, oral history, and archival sleuthing in a new and idiosyncratic way. Elizabeth Penry followed suit in The People are King: The Making of an Indigenous Andean Politics (2019). This is a novel transatlantic study that compares rebellions in Spain going back to the early sixteenth century comuneros with the peasant revolts arising in the central Andes in the late eighteenth century. Much like Abercrombie's work, it is curiously "Hispanist" and "indigenista" at the same time.

As in the case of the New Philologists, there seems to be a movement toward reconciliation with the Hispanic world among Andean ethnohistorians. That is, this ethnohistory does not seek only to emphasize native American cultural survival, as vitally important as this is, but also to reckon with hybridization or re-combinations. To simply say that Mexico or the Andes were gradually Hispanized does not explain anything. Neither do we learn much by focusing only on what looks like rejection of Hispanic impositions. Others who focused on Andean indigenous uprisings of the late eighteenth century include the late Ward Stavig (1999), Argentine-born historian Sergio Serulnikov (2003, 2013), and David T. Garrett. In Shadows of Empire (2005), Garrett, a student of Herbert Klein, reveals the complex and contradictory world of Cuzco's indigenous nobles on the eve of revolution.

Put simply, not everyone was ready to overturn the colonial order. The risks of attempting to do so were enormous, as Charles Walker's Túpac Amaru Rebellion (2016) amply shows. Again, earlier scholarly juxtapositions of "victors" and "vanquished" (like Albert Memmi's "colonizer" and "colonized") have been put to the test by colonial records, which suggest constant negotiation amid shifting imperial policy and demographic realities. Resistance was far from unknown, but as historians of slavery learned long ago, understanding its forms requires close reading and deep empathy.

In Ecuador, Frank Salomon, trained in anthropology by John V. Murra, used colonial records to expose a late-colonial hoax: the Kingdom of the Shyris, propagated by the exiled Jesuit historian Juan de Velasco (1986). Salomon has since worked in Peru, where he is among the leading scholars of the indigenous record-keeping system known as the quipu or khipu. Salomon also published essential documents in Quechua such as the early seventeenth-century Huarochirí Manuscript along with George Urioste and others. Like Murra, Salomon has remained most interested in prying open indigenous worlds that "mainstream" colonial historians might not be bold enough to enter.

Wisconsin-trained historian Susan Ramírez has blended ethnohistorical and more traditional methods in tracing the colonial history of north coastal Peru in a string of important monographs. Ramírez was among the early scholars to point out the significance of upstart caciques in colonial political economy. In Ecuador, Karen Vieira Powers, a student of Nicolás Sánchez-Albornoz, followed her mentor's lead in tracing the migratory paths of indigenous commoners as well as the opportunistic workings of certain native elites. Steve Stern student Rachel O'Toole has blended ethnohistory with the history of race and gender in her pioneering work on Trujillo and the Lambayeque Valley. In particular, O'Toole has shown how deeply entwined slavery and indigenous draft labor were in this region of Peru beginning in the sixteenth century. 
Much like certain New Philologists in Mexico, Andeanists have lately turned to examine indigenous elites and intellectuals in Peru. Alcira Dueñas, Gonzalo Lamana, and José Carlos de la Puente Luna stand out. Sean McEnroe has just contributed a comparative, hemispheric study of indigenous intellectuals (2020). These may be thought of in part as stories of "Hispanization" but such a characterization risks trivializing or unfairly reducing a much more complex process of colonial transformation. Continued interest in what used to be called the Spiritual Conquest has also inspired more penetrating work on colonial Quechua by linguistically minded Andeanist scholars such as John Charles, Alan Durston, and Regina Harrison, leading us back to the old theme of Hispanization as the creation of a "New World" Roman Catholicism.

\section{A RELIGIOUS RETURN}

Colonial Latin Americanists in the U.S. have long been drawn to the fraught history of the Catholic Church, both as multi-layered institution and as "bottom-up" cultural force. In this, we return to large-bore Hispanism in that the topic itself demands deep understanding of the Spanish evangelization project even if the scholar's interest is in what was on the minds of those who subverted or rejected it. One might distinguish between Church history per se vs. popular religiosity, including resistance or heterodoxy.

Colonial Spanish American Church history in the twentieth century ranged from studies of diocesan and regular clergy to the workings of the Holy Office of the Inquisition to convent life. Some scholars traced the careers of individual nuns or priests, but mostly this was institutional history, laying down the building blocks for further inquiry. Studies of the Inquisition were fairly split from the beginning between studies of the institution and works on the persecution of specific religious minorities and their tenacious attempts to survive.

Richard Greenleaf was long a fixture at Tulane University, a leading scholar of the Mexican Inquisition and of the Catholic Church in colonial Latin America more broadly. Other scholars explored religious themes in different ways in the 1970s and 1980s. Nancy Farriss, who taught at the University of Pennsylvania until 2016, did early work on the Mexican clergy before making a mark in the ethnohistory of the Yucatán. Her Maya Society Under Spanish Rule (1984) was inspired in part by Charles Gibson's book on the "Aztecs". Farriss has returned to religious history with Tongues of Fire: Language and Evangelization in Colonial Mexico (2018), which focuses on Oaxaca. A student of Farriss now training her own students, Gabriela Ramos, has followed similar trends in Peru, beginning with Death and Conversion in the Andes (2010).

Stafford Poole, a priest and scholar, was fundamental in translating some of Las Casas' Latin texts beginning in the early 1970s when this was being hotly debated, and he went on to publish controversial books on the Virgin of Guadalupe in Mexico $(1995,2003)$. In the eyes of some Poole's "exposure" of the Guadalupe legend bordered on heresy, but he was keen to balance "historical transparency" with hagiographic traditions. Poole has been among the few to combine techniques from the New Philology with more traditional Church history. John "Fritz" Schwaller is another such scholar of expansive range, and he has published in collaboration with Poole. In 1985, Schwaller produced a deeply researched study of early colonial Mexican church finances followed by several broader books on Church history and the history of the Franciscan Order in the Americas. Schwaller has since moved out of institutional and economic history to publish works in the New Philology and New Conquest History modes.

If there was a notable Post-Cold War 'religious turn' it was away from the social science emphasis on statistics and models - and from institutions as structures - and more toward cultural matters and indigenous or subaltern perspectives. Some of this new work was 
influenced by older studies by French scholars Robert Ricard and Pierre Duviols, focused in part on the so-called Spiritual Conquest of the Americas or its failure. But it was arguably the more 'ethnographic' work of historians like Carlo Ginzburg and Natalie Zemon Davis in European history that pushed historians to dig deeper in search of lost or hidden mentalities. Another influence was the U.S. anthropologist Clifford Geertz, famous for "thick description".

The Canadian historian Kenneth Mills broke new ground in Idolatry and Its Enemies (1996), a deeply layered study of Peru's seventeenth-century campaigns to "extirpate" indigenous religious practices, mostly in the large archdiocese of Lima. Mills showed how the spiritual conquest (a term used by contemporary priests) was hardly the success that its proponents claimed, but also that under certain powerful clergymen the Extirpación took on institutional forms that mimicked the Holy Office of the Inquisition, which was formally excluded from indigenous affairs. Nicholas Griffiths $(1996,1999)$ and Claudia Brosseder (2014) have shown further how the "Hispanic" struggle against Andean "idolatry" revealed hidden worlds while eliding Inquisitorial procedure, as has anthropologist Irene Silverblatt in Moon, Sun, and Witches (1987) and Modern Inquisitions (2005). This was a violent "Hispanization" that mirrored processes in Mexico chronicled by David Tavárez.

Also working in the Andes was Sabine MacCormack (1941-2012), a German-born, Oxford-trained scholar who ended her peripatetic career at the University of Notre Dame. McCormack's Religion in the Andes (1991) was a revelation for many Latin Americanists who lacked training in Latin and the Classics. Trained as a Classicist, McCormack showed how Spanish clergymen in the Andes conceived of their tasks in ways inspired by or reminiscent of classical predecessors. Their ability to convert native Andeans to their way of thinking may have failed, but not for lack of education. McCormack sought to explain the complexity and ambivalence of the so-called spiritual conquest, a task she returned to in On the Wings of Time (2007).

Other scholars who have published in the "Hispanic Classicist" mode include David Lupher, whose Romans in a New World (2003) went beyond MacCormack's interest in religious misunderstandings to examine Spanish settlers' and priests' sense of their colonizing projects vis-à-vis ancient Romans (as they understood them). Also influenced by this classical strand or tradition is anthropologist Daniel Reff of Oregon State University, whose early work on demographic history was complemented by Plagues, Priests, and Demons (2005), a study comparing medieval and early Mexican writings with an eye to their classical inspirations. A quietly influential scholar in this mode has been medievalist James Muldoon, whose exegesis of the monumental work of Juan de Solórzano Pereira stands out, alongside reflections on the larger evangelization project as medieval dream $(1994,2004)$.

Always painting on a large canvas, William B. Taylor has —after foundational work on the Mexican hacienda and peasant social unrest- explored the actions and writings of priests, many of them frustrated by their inability to win "hearts and minds" among ordinary congregants, at least in the way they wanted. Bourbon attempts to curb Church power in Mexico were met with tenacious popular and priestly resistance as well.

Inspired in part by William Christian's work in Spain and Inga Clendinnen's reflections on early colonial Mexico (and her native Australia), Taylor has embraced ambivalence. In Theater of a Thousand Wonders (2017) Taylor examines the proliferation of shrines in New Spain and their highly competitive cults and propaganda campaigns. It is a history of colonial Mexican Catholicism that is also a "spiritual geography" reminiscent of the Berkeley School. In short, Taylor has taken seriously what many historical materialists (and other "anticlerical" historians) had long dismissed as smoke and mirrors and given it serious attention. Meanwhile, a student of Taylor, Karen Melvin, has revived the study of mendicant priests and their far-reaching influence in colonial Mexico (2012). We move between the 
seemingly disparate realms of collective clerical biography and popular culture or religious folklore, a reminder of what fascinated the early Hispanists going back to Washington Irving.

Also working to sort out the conversion project in early Mexico was the late Argentineborn scholar Osvaldo Pardo, who produced two superb and probing monographs, picking up on the long line of inquiry going back to Robert Ricard. Patricia Lopes Don followed with Bonfires of Culture (2010), and a new voice in this field is Ryan D. Crewe, who offers something of a counterpunch to the whole notion of spiritual conquest (2019). There are echoes here of Ricard, J. L. Phelan, Lewis Hanke, Daniel Castro, and others, but the probing is deeper, the questions harder. The Spiritual Conquest, such as it was, cannot be understood in isolation. The Canadian historian Allan Greer has pushed for more comparative work that includes the Jesuit conversion project in French Canada (2000, 2003, 2005). Inspired in part by the history of Canada, Greer has since called for a comparative North-South approach to indigenous land dispossession (2018).

New work on Franciscan missionary activity north and south includes David Rex Galindo (2018) and Cameron Jones (2019), joining a spate of new studies of the Jesuits and their competitors in Paraguay. Scholars of this region include Robert Jackson, Julia Sarreal (2014), Dot Tuer, and Shawn Austin (in press). As with the New Philologists and Andean ethnohistorians, a pressing question remains: to what degree are we talking about "Hispanization" of native Americans vs. "Americanization" of Roman Catholicism? We will return to this matter briefly below in discussing new Borderlands history.

\section{RACE AND SLAVERY IN SPANISH AMERICA}

Another trend that preceded the end of the Cold War but accelerated afterwards was the focus on race and slavery in colonial Spanish America. The Civil Rights movement in the U.S. spurred many inquiries into mestizaje, summed up in 1967 by the Swedish scholar Magnus Mörner. Others sought to illuminate the lives of enslaved and free people of African descent. For some, Spanish America (and Brazil) looked more racially "democratic" than the U.S., although with caveats (e.g., the poorest people in countries like Colombia still tended to be black). Leslie B. Rout (1935-1987), an early Minnesota PhD and accomplished jazz saxaphonist, was one of the first U.S.-based historians to test this hypothesis in a broad sense in The African Experience in Spanish America (1976). Sadly, Rout's career was cut short by hepatitis.

Another pioneer historian of colonial slavery and the Black experience in Spanish America was the West Indian scholar Colin Palmer (1944-2019), who taught for many years at Princeton after receiving his PhD at Wisconsin. Palmer's Slaves of the White God (1976) showed Anglophone readers what Mexican historian Gonzalo Aguirre Beltrán had been saying for some time: that colonial Mexico was in many places a "neo-Africa". It was much more "black" than current demographers claimed. Palmer followed up with Human Cargoes, a study of the English asiento or slave trade monopoly of the early eighteenth century (1981). Patrick Carroll reminded us that slave-based plantation agriculture was not dead on Mexico's Gulf Coast (2001), and that cities such as Veracruz retained an African cast long after the slave trade diminished in volume. Restall has shown how even in non-plantation zones such as Yucatan the population of enslaved and free Africans was substantial. Meanwhile, Ben Vinson and his students Norah Gharala and Joseph Clark have moved the story of black Veracruz forward, adding to our knowledge of the early slave trade and the persistent importance of free and enslaved women. Vinson's Before Mestizaje (2018) explores black Mexico more broadly, and Robert Schwaller's Géneros de Gente (2016) pushes the clock back to examine the curious language surrounding race mixture in the early years of New Spain.

For South America, a foundational work was Frederick Bowser's The African Slave in Colonial Peru (1975), a massive, almost encyclopedic volume. In 1976, William F. Sharp, a 
former Peace Corps volunteer, published a history of slavery in the eighteenth-century gold mines along Colombia's Pacific Coast, and the Jesuit historian Nicholas Cushner published works on slavery in Jesuit plantations in Peru (1980) and Ecuador (1983). Cheryl English Martin (University of Texas, El Paso) produced a similar study of sugar plantations and slavery in Moreles, Mexico, in 1985, as did Herman Konrad (1980).

The history of slavery and Afro-Spanish American life has burgeoned in recent years, with monographs by Sherwin Bryant, mentioned above, Joan Bristol (2007), Laura Lewis (2003), and Frank Proctor (2010). Herman Bennett has published excellent studies of the lives of enslaved and free persons of African descent in central Mexico and beyond (2003, 2009 , 2019). Tatiana Seijas, a student of Stuart B. Schwartz, opened an entirely new chapter with Asian Slaves in Colonial Mexico: From Chinos to Indians (2014). Seijas and others have done much to reconnect colonial Mexico to the Philippines and the broader Pacific. As noted above, Ben Vinson III, who started with late-colonial military history, has recently offered a new synthesis of Mexico's long denial of African roots. Pablo Sierra (2018) has renovated the history of slavery and the slave trade into and beyond Puebla in the seventeenth century.

Douglas Cope (1955-2019), a student of Steve Stern, took the larger study of race in colonial Mexico in a new direction with his 1994 book, The Limits of Racial Domination. Cope showed that in seventeenth and early eighteenth-century Mexico City the terms appearing on so-called casta paintings were not common on the street. One did not call a neighbor a lobo, much less a "throwback" (salta atrás). A more subtle language, focused on comportment and reputation, prevailed among working-class people of various hues.

Art historian Ilona Katzew in a sense confirmed Cope's findings, showing through an exhaustive study of the casta paintings themselves that old assumptions about their aim and audience were misguided. This work continued with Race and Classification: The Case of Mexican America (2009), edited by Katzew and Susan Deans-Smith.

The late Mexican-born historian María Elena Martínez (1966-2014) dove deeper with Genealogical Fictions: Limpieza de Sangre, Religion, and Gender in Colonial Mexico (2008). Working across the Atlantic to understand the roots of Mexican blood-purity obsession, Martínez did still more to demolish the old idea of a viable "caste2 system in colonial Mexico. As a historian of gender, Martínez sought to show that none of this could be understood without also parsing gendered roles, reversals, and aspirations. In short, the record shows that there was nothing fixed about colonial identities.

Reaching beyond Mexico, Ann Twinam has exploited eighteenth-century petitions for legitimacy and "whiteness" to shed new light on shifting conceptions of race, class, and respectability. One of the great strengths of these books is their sensitivity to regional context even as the core social anxieties were shared across much of the Spanish Empire, including Spain. That is the subject taken up by Antonio Feros, in his far-reaching Speaking of Spain: The Evolution of Race and Nation in the Hispanic World (2017).

What all of these books have helped to do is bury the myth of a two-part Spanish American reality: Indians vs. Spaniards, with mestizos as the unclaimed bastard children of colonialism. We have learned that Hispanic America was cosmopolitan and mixed from the start, and that this complex social milieu must be understood before we can make sense of "liminal" figures such as "La Malinche" (Malintzin), "El Inca" Garcilaso de la Vega, Guaman Poma de Ayala, and Domingo Chimalpahin. To this list we must add the Afro-Peruvian mystic Úrsula de Jesús, studied by Nancy Van Deusen, and the more reticent St. Martin de Porres, profiled by Celia Cussen.

Lest we forget class, Lyman Johnson, who co-authored a classic textbook on colonial Latin America with Mark Burkholder, has reminded us of plebeian protest in late-colonial Buenos Aires (2011). This returns us to the point made by Douglas Cope in 1994: a racist 
slur is what you call people you don't like or when you lose your temper. Class is what you live (even in a thousand-layer cake like mid-colonial Mexico City). María Elena Martínez might have added that gender is what you bend. Some readers may chafe at my use of these shopworn categories, but they are not easily replaced. A challenging new study at the junction of class, race, and gender is Sylvia Sellers-García's The Woman on the Windowsill (2020), a true crime drama from late-colonial Guatemala.

Ben Vinson III has also added a new dimension to the history of race by focusing on militiamen of color in late-colonial Mexico. Calgary-based historian Hendrik Kraay has done a similar kind of work for late-colonial Brazil. As a general rule, however, military history has remained a niche field among Anglophone colonial Latin Americanists. This may be changing with new comparative work by historians like Elena Schneider (UC Berkeley). Schneider's two-sided history of the 1762 British siege of Havana is a major revision.

\section{WOMEN AND GENDER IN SPANISH AMERICA}

The history of women and gender in colonial Latin America has grown substantially in the last few decades, in part propelled by an approaching gender balance in the field. A pioneer is Asunción Lavrin, whose long career has mostly focused on women's history in colonial Mexico, with an emphasis on cloistered women and their varied roles in society and economy. Her main findings were summed up in her capstone work, Brides of Christ (2008). Lavrin also edited a still-valuable collection on gender and sexuality in 1989 and a collection on women's history in Latin America from 1978. A contemporary of Lavrin whose work focused on late-colonial Argentina, mostly Buenos Aires, is Susan Socolow. Although not strictly a historian of women, as her first book treated merchant families and their social networks and her second book was on bureaucrats, Socolow offered an important synthesis in 1999 (now in a second edition) with Women in Colonial Latin America. Jane Mangan and Sarah Owens followed with Women of the Iberian Atlantic (2012), which bridges Spain and Spanish America, and Jane Mangan and Nora Jaffary have produced a rich volume of sources and essays called Women in Colonial Latin America, 1526 to 1806: Texts and Contexts (2018).

We have already seen how central women were in the Andean economy as shown in the works of Black, Burns, Gauderman, Graubart, Mangan, and others. With Women who Live Evil Lives (2002) Martha Few showed that power could be found in the world of herbs and midwifery, often denounced as witchcraft. Working in Mexico, Nora Jaffary focused on female mystics and their ability to slip through the male noose. Jaffary has since published a magisterial history of contraception in Mexico from colonial to modern times. And not all religious women were cloistered, as Jessica Delgado has shown in her path-breaking Laywomen and the Making of Colonial Catholicism in New Spain, 1630-1790 (2018).

The more fluid matter of gender identity has confounded colonial scholars, many of whom have struggled to decipher the story of Catalina de Erauso, the empire-trotting Basque "Lieutenant Nun". The late anthropologist Thomas Abercrombie offered something completely new in his last book with Passing to América (2018), the story of another crossdressed Spanish woman who made her home in what is today Bolivia in the late colonial period. The broader history of sexuality — in this case as deviance - is further explored for colonial Mexico by Zeb Tortorici (NYU) in Sins Against Nature: Sex and Archives in Colonial New Spain (2018). Tortorici picks up in some ways on the work of New Philologist Pete Sigal (Duke). Tortorici and Martha Few have in turn apprised us of the need to look at animals in colonial Latin America as well.

All of this takes us back to the question of Hispanism. How might "Spanish America" have looked without Roman Catholic priests and nuns, and without the Inquisition and 
idolatry extirpation campaigns? It seems impossible to imagine, yet scholarship on religious matters demands a capacious approach, short-circuiting generalization. If women were oppressed by a peculiarly Hispanic form of patriarchy in the colonial period, what forms did this patriarchy take and how might it have been subverted? A related matter, traditionally tied to the Black Legend of Spanish obscurantism and Inquisition censorship is the history of science.

\section{SCIENCE, ENLIGHTENMENT, AND THE LAW}

The history of science, technology, and medicine in colonial Spanish America has fairly bloomed in recent years. Along with this has come renewed interest in the Spanish and Spanish-American Enlightenment as well as new approaches to colonial law. A vocal proponent of this new wave has been the Ecuador-born historian Jorge Cañizares-Esguerra. Cañizares-Esguerra threw down the gauntlet with How to Write the History of the New World (2001), followed by a series of provocative books and essays challenging historians of the British Atlantic and colonial North America to rethink their assumptions about HispanicAmerican "obscurantism" (2006, 2018).

Other historians have shed new light on the great Spanish scientific expeditions of the eighteenth century. In Visible Empire (2012), Daniela Bleichmar, who straddles history and art history, revealed the often forgotten complexity of representation in a pre-photographic world. Bleichmar also reminded scholars obsessed with Mexico that the natural history of New Granada, revealed by scholars such as the gaditano José Celestino Mutis, later drew the interest of polymaths like Alexander von Humboldt. Bleichmar also joined a larger wave of renewed interest in the Malaspina expeditions to the Pacific. Others have examined the mining and metallurgy expeditions sponsored by Charles III and IV.

Martha Few has recently delved more deeply into the history of medicine in For All of Humanity (2015), an examination of Charles IV's smallpox vaccination campaign and its mixed consequences in Guatemala. Paul Ramírez has also treated the smallpox vaccination campaign in Enlightened Immunity (2018), focused on Mexico. Adam Warren has examined population growth policy in Bourbon Peru (2010) and many aspects of colonial medicine, from folk to physician. Matthew Crawford has explored the dissemination of quinine in The Andean Wonder Drug (2016), picking up on the classic work of physician Saul Jarcho (1991). Pushing the history of medicine back to the sixteenth and seventeenth centuries, and out of the Hispanic realm is Pablo F. Gómez's breakthrough book The Experiential Caribbean (2017). Marcy Norton has forced us to reconsider commodities and foods (2008), as has Rebecca Earle, who forces us to reconsider early modern Spanish notions of the body (2012).

Bianca Premo, whose first works focused on children and the family in Peru, has turned to the larger matter of the Spanish and Spanish-American Enlightenment. In addition to broadening our understanding of eighteenth-century mentalities, Enlightenment on Trial: Ordinary Litigants and Colonialism in the Spanish Empire (2017) is also a new form of legal history "from the bottom up". In a way it resembles the big arguments regarding a folk skepticism that was long brewing or bubbling to the surface only intermittently, described in delightful detail in Stuart B. Schwartz's counterintuitive study of the Inquisition, All Can Be Saved: Religious Tolerance and Salvation in the Iberian Atlantic World (2008). It is just the sort of "Hispanic" —or in this case, "Luso-Hispanic" — book that Schwartz's mentor, Lewis Hanke, would have appreciated.

Along with Bianca Premo, just mentioned, innovative scholars of the law in colonial Spanish America include Christopher Albi, Adrian Masters, Matthew Mirow, Michelle McKinley, Yanna Yannakakis, Bianca Premo, and Tamar Herzog, which leads us back to 
bureaucrats or letrados. Mark Burkholder led a trend in the study of royal bureaucrats, developing some of the concerns identified by J. L. Phelan into the eighteenth century, mostly focused on Peru. Burkholder, like Phelan, was interested in escaping the nationalist box that could never really hold these peripatetic letrados and military men, some of whose careers spanned the globe. Linda Arnold followed a similar track in her work on late-colonial bureaucrats in Mexico (1988), as did Susan Socolow for Buenos Aires (1987).

In recent years, historians have approached bureaucratic activities from quite different angles. Kathryn Burns examined notaries in Into the Archive (2010), Cynthia Milton examined poor relief in The Many Meanings of Poverty (2011), and Jeremy Mumford reexamined Viceroy Toledo's ambitious and cruel resettlement project in sixteenth-century Peru in Vertical Empire (2012). Bruce Castleman explored the multifaceted history of New Spain's Camino Real system (2005), and finally, Sylvia Sellers-García followed Bourbon postal workers all over Guatemala (2014). Returning to letrados, it may be time to follow the complex, intercontinental careers and social networks of these long forgotten public (or royal) servants, perhaps the most prominent and durable "missionaries of Hispanism". A recent dissertation by Adolfo Polo, a student of Alejandro Cañeque, takes exactly this tack, following Spanish bureaucrats to the outer limits of empire in the seventeenth century.

\section{LATIN AMERICAN LITERATURE AND THE NEW HISTORICISM}

I must note briefly (and insufficiently) the importance of literature and literary criticism in the field of Hispanic and Hispanic American studies since the end of the Cold War. A towering figure has been Rolena Adorno. Taking an approach sometimes identified as "New Historicism", Adorno has re-shaped the Spanish American canon in numerous ways. Her best-known work is on the indigenous Andean writer Felipe Guaman Poma de Ayala, whose 1615 letter to Philip III is housed in the Danish Royal Library in Copenhagen. But Adorno has reflected on many of the issues outlined in this essay, from Columbus to Bolívar, and from Salamanca to Santiago de Chile. Adorno's 2007 Polemics of Possession confronts the problems and promise of colonial Spanish, Spanish-American, and indigenous literature in the broadest sense. Unlike most historians, Adorno grapples openly with the troubled histories of memory, national mythology, and commemoration.

Meanwhile, literary scholar Ralph Bauer has argued for a hemispheric perspective on early American literature in ways resembling Jorge Cañizares-Esguerra's arguments for history. In a way, Bauer's calls resemble Bolton's claims for a "Greater America", but comparisons and wide-angle studies remain a tough sell for many scholars whose focus is more regional or even site-specific. We have seen how many colonial literary scholars have moved away from canonical works to focus on themes such as mining or piracy. Comparative literature, like comparative history, is double the work, and taking a hemispheric perspective means mastering half the world. In part for this reason, the call to "globalize" colonial Spanish American studies has had even fewer takers.

Other "cross-over" trends in colonial Latin American history and culture include an interest in pageantry and governance. An early student of material display or the cultural history of political pageantry was Richard Greenleaf's student Linda Curcio-Nagy, who broke down the festivals of Mexico City (2004). Alejandro Cañeque went further, reminding scholars of the significance of the viceroy as "the king's living image", not simply his lieutenant in the American dominions (2004). Alejandra Osorio has developed a similar history of urban spectacle and viceregal splendor for seventeenth-century Lima (2008). Frances Ramos has connected this line of "spectacular" research to resistance to Bourbon reforms in early eighteenth-century Puebla, Mexico (2012). And finally, literary scholar Lisa Voigt has combined an interest in mining and pageantry in Spectacular Wealth: The Festivals of 
Colonial South American Mining Towns (2016), which compares Potosí and the "other" Vila Rica, Ouro Prêto, Brazil. Voigt's first book, Writing Captivity in the Early Modern Atlantic (2009) was also comparative, breaking out of the strictly "Hispanic" mold from the beginning.

What remains to be done perhaps is to "globalize" Hispanic American studies, but as just noted this is no small task. Yet "global Hispanism" has at least one champion. Indeed, perhaps the most active "Hispanist" among Anglophone historians writing about colonial Latin America in the U.S. (and U.K.) today is Felipe Fernández-Armesto. An Anglo-British scholar based in part at the University of Notre Dame, Fernández-Armesto has worked hard to globalize "Hispanic Studies" and also to "Hispanize" U.S. History. He has argued for a reckoning without a rush to judgment, a proposition that would resonate with Lewis Hanke, H. E. Bolton, and other predecessors, but one that seems doomed by the polemics, conspiratorial ideas, and speed of communication of the current moment. FernándezArmesto has nevertheless done much to stave off the madness, and it may be fitting to end with him since he cannot be readily categorized within the U.S. Academy. Suffice to say that for Fernández-Armesto, non sufficit orbis.

\section{CONCLUDING REMARKS}

Any attempt at historiographical overview is bound to leave out scholars of great importance, either because they slipped the writer's mind or they simply fall outside the boundaries of a contrived taxonomy and genealogy. For example, a category such as "The Revolutionary Hispanic Atlantic" would include essential works by Ada Ferrer, Matt Childs, Aline Helg, Marixa Lasso, Graham Nessler, Karen Racine, Christopher SchmidtNowara, Rebecca Scott, Cristina Soriano, and many others. Important books altering our understanding of colonial Hispanic America are appearing at a faster pace than ever. In a radical revision, Marcela Echeverri argues for a persistent royalism among enslaved and indigenous peoples in southwest Colombia on the eve of independence (2016). There is much more.

I have boxed in some scholars just as I have boxed out others, but my aim has not been exclusive but rather to provide a rough guide to the main trends in colonial Latin American history as practiced in the U.S. and Canada since the early nineteenth century -all with a weather eye on the ambivalent term "Hispanism". These days it seems to lurk not on the horizon but in the rear-view mirror.

One may say that the urge to defend Spain against the claims of the Black Legend has faded with time, particularly as scholarship on indigenous peoples, slaves, women, mestizos, and other underrepresented groups - plus the complexities and ironies of colonial life for all parties - become more widely known. Even so, popular perceptions of the Spanish conquest and of the colonial period remain reflexively negative if not totally abhorrent.

As a countercurrent of sorts, the rise of ethnohistory and sub-fields such as the New Conquest History have emphasized indigenous survival, parallel agendas, even post-contact native imperialism, but thus far this seems not to have changed public perceptions of Spanish cruelty and greed. The same might be said for studies of the Inquisition, which have shown this institution to have been brutal, to be sure, but far less consistent, much less hegemonic or arbitrary than once believed. It appears that many if not most people in colonial Spanish America lived outside the Holy Office's reach. An argument for a "weakened" Inquisition has not gained traction in the Anglophone popular imagination, not helped, it may be said, by salacious "torture museums" in places like Mexico City, Cartagena, and Lima. And despite revealing new work in the history of science, popular perceptions of Hispanic obscurantism and Inquisition censorship remain strong. 
As for the shifting cast, casta, and geographical range of scholars of colonial Latin American History in the Anglophone world, what was once a white male (and surprisingly Protestant)-dominated field seems to be approaching gender parity. Scholars of indigenous, African, Asian, and Hispanic heritage are still too few, but their numbers are growing. The same may be said for underrepresented gender identities. Regional focus or "geographical equity" is a continuing concern. As the works described above show, Anglophone studies of "Hispanic America" in the colonial period have overwhelmingly concentrated on Mexico. This is understandable given Mexico's proximity to the U.S. and Canada, but there has been a tendency to neglect much of Spanish South America in the classroom and in the field. Studies of the Spanish Caribbean are starting to move beyond Cuba and Puerto Rico, and scholarship on colonial Central America is also on the rise. Gaps are slowly filling in, in other words, and considerable attention continues to be given to the so-called U.S. Borderlands, now with a better sense of indigenous agendas and agency, as well as a new consciousness of the tenacious persistence of slavery.

Intellectually, the specter of Hispanic "colonial legacies" still hovers in the background, but a peculiar more-or-less Anglophone scholarly preference for feigned neutrality often seems to keep the ghost at bay. Some colonialists fear or simply wave off talk of "underdevelopment" as anachronistic, and others seek to rehabilitate colonial Spanish sophistication in science, technology, finance, law, and so on, leaving modern Latin American problems to the post-independence era. Tensions mostly appear when crossing disciplinary lines to anthropology and literary studies. As in the history of Spain, popular fascination with conquest and religious intolerance is complicated if not neutralized by narratives of convivencia and mestizaje. Even seemingly uncontroversial topics such as "Hispanic landscapes" are filled with old presumptions and stereotypes such as the "ecological Indian" or the "greedy, short-sighted Spaniard". These inverse images of "colonizer" and "colonized" have died hard despite decades of scholarship showing that three centuries of colonial rule left virtually no living thing, from germs to humans, unchanged. The Hispanic legacy, in broadest terms, has proved nearly incalculable, a point first made forcefully by geographer Carl Sauer and elaborated by Alfred Crosby.

Overall, it is clear that Anglophone North American scholars have been interested in colonial Spanish America since the birth of the U.S. republic (or entrance to the Commonwealth, in the case of Canada), and the field has grown substantially in the last few decades, still riding the Cold War tide of Area Studies. What remains to be seen is how this longstanding interest will adapt to newly uncertain national and global roles of U.S. and Canadian universities. As federal support for area studies dries up, what arguments will be put forth to defend the quest to understand the sweeping and (by American standards) ancient Hispanic legacy of our shared hemisphere? Perhaps, taking a page from Washington Irving, this brief inquiry into North American "colonial Hispanism" should be placed in a capsule and hidden in a hollow tree, to be reopened like Rip Van Winkle's eyes in twenty years.

\section{BIBLIOGRAPHY}

Abercrombie, T. A., Passing to América: Antonio (née María) Yta's Transgressive, Transatlantic Life in the Twilight of the Spanish Empire, University Park, Penn State University Press, 2018.

- Pathways of Memory and Power: Ethnography and History among an Andean People, Madison, University of Wisconsin Press, 1998.

Adelman, J. (ed.), Colonial Legacies: The Problem of Persistence in Latin American History, New York, Routledge, 1999.

Adorno, R., The Polemics of Possession in Spanish American Narrative, New Haven, Yale 
University Press, 2007.

Adorno, R., "Washington Irving's Romantic Hispanism and its Columbian Legacies" en Kagan, R. (ed.), Spain in America: The Origins of Hispanism in the United States, Urbana, University of Illinois Press, 2002, pp. 49-105.

Alchon, S., A Pest in the Land: New World Epidemics in a Global Perspective, Albuquerque, University of New Mexico Press, 2003.

Anderson, B., Under Three Flags: Anarchism and the Anti-Colonial Imagination, London, Verso, 2005.

Andrien, K. J. and Kuethe, A. J., The Spanish Atlantic World in the Eighteenth Century: War and the Bourbon Reforms, 1713-1796, New York, Cambridge University Press, 2014.

Andrien, K. J., Andean Worlds: Indigenous History, Culture, and Consciousness under Spanish Rule, 1532-1825, Albuquerque, University of New Mexico Press, 2001.

- The Kingdom of Quito, 1690-1830: The State and Regional Development, New York, Cambridge University Press, 1995.

- Crisis and Decline: The Viceroyalty of Peru in the Seventeenth Century, Albuquerque, University of New Mexico Press, 1985.

Arnold, L., Bureaucracy and Bureaucrats in Mexico City, 1742-1835, Tucson, University of Arizona Press, 1988.

Bakewell, P. J., Silver and Entrepreneurship in Seventeenth-Century Potosí: The Life and Times of Antonio López de Quiroga, Albuquerque, University of New Mexico Press, 1988.

- Miners of the Red Mountain: Indian Labor in Potosí, 1545-1650, Albuquerque, University of New Mexico Press, 1984.

- Silver Mining and Society in Colonial Mexico: Zacatecas, 1546-1700, Cambridge, Cambridge University Press, 1971.

Baskes, J., Staying Afloat: Risk and Uncertainty in Spanish Atlantic World Trade, 17601820, Stanford, Stanford University Press, 2013.

- Indians, Merchants, and Markets: A Reinterpretation of the Repartimiento and SpanishIndian Economic Relations in Colonial Oaxaca, 1750-1821, Stanford, Stanford University Press, 2000.

Bauer, R., The Alchemy of Conquest: Science, Religion, and the Secrets of the New World, Charlottesville, University of Virginia Press, 2019.

- "Early American Literature and American Literary History at the «Hemispheric Turn»", Early American Literature, 45:2 (2010), pp. 217-33.

- "Laying Claim to the Literary Borderlands: The Contested Grounds of Hispanism in the U.S.", American Literary History, 16:3 (fall 2004), pp. 487-95.

Bennett, H. L., African Kings and Black Slaves: Sovereignty and Dispossession in the Early Modern Atlantic, Philadelphia, University of Pennsylvania Press, 2019.

- Colonial Blackness: A History of Afro-Mexico, Bloomington, Indiana University Press, 2009.

- Africans in Colonial Mexico: Absolutism, Christianity, and Afro-Creole Consciousness, 1570-1640, Bloomington, Indiana University Press, 2003.

Bentancor, O., The Matter of Empire: Metaphysics and Mining in Colonial Peru, Pittsburgh, University of Pittsburgh Press, 2017.

Benton, B., Lords of Tetzcoco: The Transformation of Indigenous Rule in Postconquest Central Mexico, New York, Cambridge University Press, 2017.

Bigelow, A., Mining Language: Indigenous Knowledge and Colonial Metallurgy in the Early Modern Iberian World, Chapel Hill, University of North Carolina Press, 2020.

Bleichmar, D., Visible Empire: Botanical Expeditions and Visual Culture in the Hispanic 
Enlightenment, Chicago, University of Chicago Press, 2012.

Bowser, F. P., The African Slave in Colonial Peru, 1524-1650, Stanford, Stanford University Press, 1974.

Brading, D., Mexican Phoenix: Our Lady of Guadalupe: Image and Tradition across Five Centuries, New York, Cambridge University Press, 2001.

- The First America: The Spanish Monarchy, Creole Patriots, and the Liberal State, 14921867, Cambridge, Cambridge University Press, 1991.

- Haciendas and Ranchos in the Mexican Bajío: León, 1700-1860, Cambridge, Cambridge University Press, 1978.

- Miners and Merchants in Bourbon Mexico, 1763-1810, Cambridge, Cambridge University Press, 1971.

Brosseder, C., The Power of Huacas: Change and Resistance in the Andean World of Colonial Peru, Austin, University of Texas Press, 2014.

Brown, T., Pueblo Indians and Spanish Colonial Authority in Eighteenth-Century New Mexico, Tucson, University of Arizona Press, 2013.

Bryant, S. K., Rivers of Gold, Lives of Bondage: Governing through Slavery in Colonial Quito, Chapel Hill, University of North Carolina Press, 2014.

Bryant, S. K., O'Toole, R. S. and Vinson III, B. (eds.), Africans to Spanish America: Expanding the Diaspora, Urbana, University of Illinois Press, 2012.

Buechler, R. M., The Mining Society of Potosí, 1776-1810, Syracuse, Syracuse University, 1981.

Burkholder, M., Spaniards in the Colonial Empire: Creoles vs. Peninsulars? Malden, MA, Wiley-Blackwell, 2013.

- Politics of a Colonial Career: José Baquijano and the Audiencia of Lima, Albuquerque, University of New Mexico Press, 1980.

Burns, K., Into the Archive: Writing and Power in Colonial Peru, Durham, Duke University Press, 2010.

- Colonial Habits: Convents and the Spiritual Economy of Cuzco, Peru, Durham, Duke University Press, 1999.

Candiani, V. S., Dreaming of Dry Land: Environmental Transformation in Colonial Mexico City, Stanford, Stanford University Press, 2014.

Cañeque, A., Un cuerpo de dos cabezas. La cultura política del poder en la Nueva España, siglos XVI y XVII, Méjico, Ediciones EyC, 2018.

- The King's Living Image: The Culture and Politics of Viceregal Power in Colonial Mexico, New York, Routledge, 2004.

Cañizares-Esguerra, J. (ed.), Entangled Empires: The Anglo-Iberian Atlantic, 1500-1830, Philadelphia, University of Pennsylvania Press, 2018.

- Nature, Empire, and Nation: Explorations of the History of Science in the Iberian World, Stanford, Stanford University Press, 2006.

- Puritan Conquistadors: Iberianizing the Atlantic, 1550-1700, Stanford, Stanford University Press, 2006.

- How to Write the History of the New World: Histories, Epistemologies, and Identities in the Eighteenth-Century Atlantic World, Stanford, Stanford University Press, 2001.

Castro, D., Another Face of Empire: Bartolomé de las Casas, Indigenous Rights, and Ecclesiastical Imperialism, Durham, Duke University Press, 2007.

Charles, J., Allies at Odds: The Andean Church and its Indigenous Agents, 1583-1671, Albuquerque, University of New Mexico Press, 2010.

Chevalier, F., Land and Society in Colonial Mexico: The Great Hacienda, trans. Alvin Eustis, Berkeley, University of California Press, 1963. 
Christensen, M. Z., Nahua and Maya Catholicisms: Texts and Religion in Colonial Central Mexico and Yucatán, Stanford, Stanford University Press, 2013.

Cline, S. L., Colonial Culhuacan, 1580-1600: A Social History of an Aztec Town, Albuquerque, University of New Mexico Press, 1986.

Connell, W. F., After Moctezuma: Indigenous Politics and Self-Government in Mexico City, 1524-1730, Norman, University of Oklahoma Press, 2011.

Corbeil, L., The Motions Beneath: Indigenous Migrants on the Urban Frontier of New Spain, Tucson, University of Arizona Press, 2018.

Couturier, E., The Silver King: The Remarkable Life of the Count of Regla in Colonial Mexico, Albuquerque, University of New Mexico Press, 2003.

Crewe, R. D., The Mexican Mission: Indigenous Reconstruction and Mendicant Enterprise in New Spain, 1521-1600, New York, Cambridge University Press, 2019.

Cruz, A. J. and Hernández, R. (eds.), Women's Literacy in Early Modern Spain and the New World, Burlington, VT, Ashgate, 2011.

Cruz, A. J., "American Hispanism(s)", South Atlantic Review, 73:4 (fall 2008), pp. 86-106.

Cruz, A. J., and Perry, M. E. (eds.), Cultural Encounters: The Impact of the Inquisition in Spain and the New World, Berkeley, University of California Press, 1991.

Curcio-Nagy, L., The Great Festivals of Colonial Mexico City: Performing Power and Identity, Albuquerque, University of New Mexico Press, 2004.

Curtin, P. D., The Rise and Fall of the Plantation Complex: Essays in Atlantic History, New York, Cambridge University Press, 1998.

Cushner, N., Why Have You Come Here? The Jesuits and the First Evangelization of Native America, New York, Oxford University Press, 2006.

Cutter, C., The Legal Culture of Northern New Spain, 1700-1810, Albuquerque, University of New Mexico Press, 1995.

Dean, C., Inka Bodies and the Body of Christ: Corpus Christi in Colonial Cuzco, Peru, Durham, Duke University Press, 1999.

Asúa, M. de, Science in the Vanished Arcadia: Knowledge of Nature in the Jesuit Missions of Paraguay and Río de la Plata, Leiden, Brill, 2014.

Fuente, A. de la, Havana and the Atlantic in the Sixteenth Century, Chapel Hill, University of North Carolina Press, 2008.

Puente Luna, J. C. de la, Andean Cosmopolitans: Seeking Justice and Reward at the Spanish Royal Court, Austin, University of Texas Press, 2018.

Deeds, S., Defiance and Deference in Mexico's Colonial North: Indians under Spanish Rule in Nueva Vizcaya, Austin, University of Texas Press, 2003.

Delgado, J. L., Laywomen and the Making of Colonial Catholicism in New Spain, 16301790, New York, Cambridge University Press, 2018.

Denevan, W. M., The Native Population of the Americas in 1492, Madison, University of Wisconsin Press, 1992.

Denevan, W. M. (ed.), Carl Sauer on Culture and Landscape: Readings and Commentaries, Baton Rouge, Louisiana State University Press, 2009.

Dueñas, A., Indians and Mestizos in the "Lettered City": Reshaping Justice, Social Hierarchy, and Political Culture in Colonial Peru, Boulder, University Press of Colorado, 2010.

Earle, R., Body of the Conquistador: Food, Race, and the Colonial Experience in Spanish America, 1492-1700, New York, Cambridge University Press, 2012.

Echeverri, M., Indian and Slave Royalists in the Age of Revolution: Reform, Revolution, and Royalism in the Northern Andes, 1780-1825, New York, Cambridge University Press, 2016.

Farriss, N. M., Tongues of Fire: Language and Evangelization in Colonial Mexico, New York, 
Oxford University Press, 2018.

- Maya Society under Colonial Rule: The Collective Enterprise of Survival, Princeton, Princeton University Press, 1984.

- Crown and Clergy in Colonial Mexico, 1759-1821: The Crisis of Ecclesiastical Privilege, London, Athlone Press, 1968.

Fernández-Armesto, F., Our America: A Hispanic History of the United States, New York, W.W. Norton, 2014.

- Americas: A Hemispheric History, New York, Modern Library, 2003.

Feros, A., Speaking of Spain: The Evolution of Race in the Hispanic World, Cambridge, MA, Harvard University Press, 2017.

Ferry, R. J., The Colonial Elite of Early Caracas, Berkeley, University of California Press, 1987.

Few, M., For All of Humanity: Mesoamerican and Colonial Medicine in Enlightenment Guatemala, Tucson, University of Arizona Press, 2015.

- Women Who Live Evil Lives: Gender, Religion, and the Politics of Power in Colonial Guatemala, Austin, University of Texas Press, 2002.

Flint, S. C., No Mere Shadows: Faces of Widowhood in Early Colonial Mexico, Albuquerque, University of New Mexico Press, 2013.

Folsom, R., The Yaquis and the Empire: Violence, Spanish Imperial Power, and Native Resilience in Colonial Mexico, New Haven, Yale University Press, 2014.

Gallup-Díaz, I., The Door of the Seas and Key to the Universe: Indian Politics and Imperial Rivalry in the Darién, 1640-1750, New York, Columbia University Press, 2004.

Garrett, D. T., Shadows of Empire: The Indian Nobility of Cusco, 1750-1825, New York, Cambridge University Press, 2005.

Gauderman, K., Women's Lives in Colonial Quito: Gender, Law, and Economy in Spanish America, Austin, University of Texas Press, 2003.

Gerhard, P., The North Frontier of New Spain, Norman, University of Oklahoma Press, 1993.

- Pirates on the West Coast of New Spain, 1575-1742, Glendale, CA, Arthur H. Clark, 1960.

Gómez, P. F., The Experiential Caribbean: Creating Knowledge and Healing in the Early Modern Atlantic, Chapel Hill, University of North Carolina Press, 2017.

Graubart, K., With Our Labor and Sweat: Indigenous Women and the Formation of Colonial Society in Peru, 1550-1700, Stanford, Stanford University Press, 2007.

Green, R. L., Tropical Idolatry: A Theological History of Catholic Colonialism in the Pacific World, 1568-1700, Boulder, CO, Lexington Books, 2018.

Greenleaf, R. E. (ed.), The Roman Catholic Church in Colonial Latin America, New York, Alfred A. Knopf, 1971.

Greenleaf, R. E., The Mexican Inquisition of the Sixteenth Century, Albuquerque, University of New Mexico Press, 1969.

Greer, A., Property and Dispossession: Natives, Empires, and Land in Early Modern North America, New York, Cambridge University Press, 2018.

Greer, A. and Bilinkoff, J. (eds.), Colonial Saints: Discovering the Holy in the Americas, 1500-1800, New York, Routledge, 2003.

Griffiths, N. and Cervantes, F. (eds.), Spiritual Encounters: Interactions between Christianity and Native Religions in Colonial America, Lincoln, University of Nebraska Press, 1999.

Griffiths, N., The Cross and the Serpent: Religious Repression and Resurgence in Colonial Peru, Norman, University of Oklahoma Press, 1996.

Guerrero, S., Silver by Fire, Silver by Mercury: A Chemical History of Silver Refining in New Spain and Mexico, 16th to 19th Centuries, Leiden, Brill, 2017. 
Gutiérrez, R., When Jesus Came, the Corn Mothers Went Away: Marriage, Sexuality, and Power in New Mexico, 1500-1846, Stanford, Stanford University Press, 1991.

Haskett, R. S., Visions of Paradise: Primordial Titles and Mesoamerican History in Cuernavaca, Norman, University of Oklahoma Press, 2005.

Herzog, T., Frontiers of Possession: Spain and Portugal in Europe and the Americas. Cambridge, MA: Harvard University Press, 2015.

- Defining Nations: Immigrants and Citizens in Early Modern Spain and Spanish America, New Haven, Yale University Press, 2003.

- Upholding Justice: Society, State, and the Penal System in Quito (1650-1750), Ann Arbor, University of Michigan Press, 2004.

Hoberman, L. S. and Socolow, S. (eds.), The Countryside in Colonial Latin America, Albuquerque, University of New Mexico Press, 1996.

- Cities and Society in Colonial Latin America, Albuquerque, University of New Mexico Press, 1986.

Hoberman, L. S., Mexico's Merchant Elite, 1590-1660: Silver, State, and Society, Durham, Duke University Press, 1991.

Irving, W., A History of the Life and Voyages of Christopher Columbus, London, John Murray, 1828.

Jackson, R. H., Communities on a Frontier in Conflict: The Jesuit Guaraní Mission Los Santos Mártires del Japón, Newcastle, UK, Cambridge Scholars, 2018.

Jaksić, I., The Hispanic World and American Intellectual Life, 1820-1880, New York, Palgrave Macmillan, 2007.

Jaffary, N. E., Reproduction and its Discontents in Mexico: Childbirth and Contraception from 1750-1905, Chapel Hill, University of North Carolina Press, 2016.

- False Mystics: Deviant Orthodoxy in Colonial Mexico, Lincoln, University of Nebraska Press, 2004.

Jaffary, N. E. (ed.), Gender, Race, and Religion in the Colonization of the Americas, Aldershot, Ashgate, 2007.

Johnson, L. L., Workshop of Revolution: Plebeian Buenos Aires and the Atlantic World, 1776-1810, Durham, Duke University Press, 2011.

Jones, G. D., Maya Resistance to Spanish Rule: Time and History on a Colonial Frontier, Albuquerque, University of New Mexico Press, 1989.

Kagan, R. L., The Spanish Craze: America's Fascination with the Hispanic World, 17791939, Lincoln, University of Nebraska Press, 2019.

- "Prescott's Paradigm: American Historical Scholarship and the Decline of Spain", American Historical Review 101:2 (Apr. 1996). pp. 423-46.

Kagan, R. L. (ed.), : Spain in America: The Origins of Hispanism in the United States, Urbana, University of Illinois Press, 2002.

Katzew, I. and Deans-Smith, S. (eds.), Race and Classification: The Case of Mexican America, Stanford, Stanford University Press, 2009.

Katzew, I., Casta Painting: Images of Race in Eighteenth-Century Mexico. New Haven, Yale University Press, 2004.

Keen, B., Essays in the Intellectual History of Colonial Latin America, Boulder, CO, Westview Press, 1998.

Krippner-Martínez, J., Rereading the Conquest: Power, Politics, and the History of Early Colonial Michoacán, 1521-1565, University Park, Penn State University Press, 2001.

Lamana, G., Domination without Dominance: Inca-Spanish Encounters in Early Colonial Peru, Durham, Duke University Press, 2008.

Lane, K., Potosí: The Silver City that Changed the World, Oakland, University of California 
Press, 2019.

— Pillaging the Empire: Global Piracy on the High Seas, 1500-1750, New York, Routledge, 2015.

- Colour of Paradise: The Emerald in the Age of Gunpowder Empires, New Haven, Yale University Press, 2010.

- Quito 1599: City and Colony in Transition, Albuquerque, University of New Mexico Press, 2002.

Lanning, J. T., The Royal Protomedicato: The Regulation of the Medical Professions in the Spanish Empire, Durham, Duke University Press, 1985.

Lavrin, A., Brides of Christ: Conventual Life in Colonial Mexico, Stanford, Stanford University Press, 2008.

Lavrin, A. (ed.), Sexuality and Marriage in Colonial Latin America, Lincoln, University of Nebraska Press, 1989.

- Latin American Women: Historical Perspectives, Westport, CT, Greenwood Press, 1978.

Leibsohn, D., Script and Glyph: Pre-Hispanic History, Colonial Book Making, and the Historia Tolteca-Chichimeca, Washington, DC, Dumbarton Oaks, 2009.

Lentz, M., Murder in Mérida, 1792: Violence, Factions, and the Law, Albuquerque, University of New Mexico Press, 2018.

Leonard, I. A., Books of the Brave: Being an Account of Books and of Men in the Spanish Conquest and Settlement of the Sixteenth-Century New World, Berkeley, University of California Press, 1992.

Lockhart, J., Of Things of the Indies: Essays Old and New in Early Latin American History, Stanford, Stanford University Press, 1999.

- The Nahuas after the Conquest: A Social and Cultural History of the Indians of Central Mexico, Stanford, Stanford University Press, 1992.

- The Men of Cajamarca: A Social and Biographical Study of the First Conquerors of Peru, Austin, University of Texas Press, 1972.

- Spanish Peru, 1532-1560: A Social History, Madison, University of Wisconsin Press, 1968.

Lopes Don, P., Bonfires of Culture: Franciscans, Indigenous Leaders, and the Inquisition in Early Mexico, 1524-1540, Norman, University of Oklahoma Press, 2013.

Lovell, W. G., Conquest and Survival in Colonial Guatemala: A Historical Geography of the Cuchumatán Highlands, 1500-1821, Montréal, McGill-Queen's University Press, 2015.

Lovell, W. G. et alii (eds.), Strange Lands and Different Peoples: Spaniards and Indians in Colonial Guatemala, Norman, University of Oklahoma Press, 2013.

Lupher, D., Romans in a New World: Classical Models in Sixteenth-Century Spanish America, Ann Arbor, University of Michigan Press, 2003.

MacCormack, S., On the Wings of Time: Rome, the Incas, and Peru, Princeton, Princeton University Press, 2007.

- Religion in the Andes: Vision and Imagination in Early Colonial Peru, Princeton, Princeton University Press, 1991.

MacLachlan, C. M., Imperialism and the Origins of Mexican Culture, Cambridge, MA, Harvard University Press, 2015.

- Spain's Empire in the New World: The Role of Ideas in Institutional and Social Change, Berkeley, University of California Press, 1988.

MacLeod, M., Spanish Central America: A Socioeconomic History, 1520-1720, Berkeley, University of California Press, 1973. [2d ed. 2008]

Mangan, J. E. and Jaffary, N. E. (eds.), Women in Colonial Latin America, 1525 to 1806: Texts and Contexts, Indianapolis, Hackett Publishing, 2018. 
Mangan, J. E. and Owens, S. E. (eds.), Women of the Iberian Atlantic, Baton Rouge, Louisiana State University Press, 2012.

Mangan, J. E., Transatlantic Obligations: Creating the Bonds of Family in Conquest-Era Peru and Spain, New York, Oxford University Press, 2016.

- Trading Roles: Gender, Ethnicity, and the Urban Economy in Colonial Potosí, Durham, Duke University Press, 2005.

Martínez, M. E., Genealogical Fictions: Limpieza de Sangre, Religion, and Gender in Colonial Mexico, Stanford, Stanford University Press, 2008.

Matthew, L. E., Memories of Conquest: Becoming Mexicano in Colonial Guatemala, Chapel Hill, University of North Carolina Press, 2012.

Melvin, K. and Sellers-García, S. (eds.), Imagining Histories of Colonial Latin America: Essays on Synoptic Methods and Practices, Albuquerque, University of New Mexico Press, 2017.

Melvin, K., Building Colonial Cities of God: Mendicant Orders and Urban Culture in New Spain, Stanford, Stanford University Press, 2012.

Mignolo, W., The Darker Side of the Renaissance: Literacy, Territoriality, and Colonization, Ann Arbor, University of Michigan Press, 1995.

Miller, S. W., Fruitless Trees: Portuguese Conservation and Brazil's Colonial Timber, Stanford, Stanford University Press, 2000.

Milton, C., The Many Meanings of Poverty: Colonialism, Social Compacts, and Assistance in Eighteenth-Century Ecuador, Stanford, Stanford University Press, 2007.

Mirow, M. C., Latin American Law: A History of Private Law and Institutions in Spanish America, Austin, University of Texas Press, 2004.

Mintz, S., Sweetness and Power: The Place of Sugar in Modern History, New York, Penguin, 1985.

Muldoon, J., The Americas in the Spanish World Order: The Justification for Conquest in the Seventeenth Century, Philadelphia, University of Pennsylvania Press, 1994.

Mumford, J., Vertical Empire: The General Resettlement of the Indians in the Colonial Andes, Durham, Duke University Press, 2012.

Mundy, B. E., The Death of Aztec Tenochtitlan, the Life of Mexico City, Austin, University of Texas Press, 2015.

- The Mapping of New Spain: Indigenous Cartography and the Maps of the Relaciones Geográficas, Chicago, University of Chicago Press, 1996.

Nesvig, M., Promiscuous Power: An Unorthodox History of New Spain, Austin, University of Texas Press, 2018.

Norton, M., Sacred Gifts, Profane Pleasures: A History of Tobacco and Chocolate in the Atlantic World, Ithaca, Cornell University Press, 2008.

Owensby, B. P., Empire of Law and Indian Justice in Colonial Mexico, Stanford, Stanford University Press, 2008.

Osorio, A.: Inventing Lima: Baroque Modernity in Peru's South Sea Metropolis, New York, Palgrave Macmillan, 2008.

Paquette, G. B., The European Seaborne Empires: From the Thirty Years War to the Age of Revolutions, New Haven, Yale University Press, 2019.

- Enlightenment, Governance, and Reform in Spain and its Empire, 1759-1808, New York, Palgrave Macmillan, 2008.

Paquette, G. B. and Brown, M. (eds.), Connections after Colonialism: Europe and Latin America in the 1820s, Tuscaloosa, University of Alabama Press, 2013.

Pardo, O. F., Honor and Personhood in Early Modern Mexico, Ann Arbor, University of Michigan Press, 2015. 
- The Origins of Mexican Catholicism: Nahua Rituals and Christian Sacraments in SixteenthCentury Mexico, Ann Arbor, University of Michigan Press, 2004.

Patch, R. W., Indians and the Political Economy of Colonial Central America, 1670-1810, Norman, University of Oklahoma Press, 2013.

- Maya and Spaniard in Yucatan, 1648-1812, Stanford, Stanford University Press, 1993.

Pearce, A. J., The Origins of Bourbon Reform in Spanish South America, 1700-1763, New York, Palgrave Macmillan, 2014.

Penry, E., The People Are King: The Making of an Indigenous Andean Politics, New York, Oxford University Press, 2019.

Phelan, J. L., The People and the King: The Comunero Revolution in Colombia, 1781, Madison, University of Wisconsin Press, 1978.

- The Kingdom of Quito in the Seventeenth Century: Bureaucratic Politics in the Spanish Empire, Madison, University of Wisconsin Press, 1967.

Phillips, C., Six Galleons for the King of Spain: Imperial Defense in the Early Seventeenth Century, Baltimore, Johns Hopkins University Press, 1986.

Phillips, W. D. and Phillips, C.: The Worlds of Christopher Columbus, Cambridge, Cambridge University Press, 1992.

Pike, F. B., Hispanismo, 1898-1936: Spanish Conservatives and Liberals and their Relations with Spanish America, South Bend, Notre Dame University Press, 1971.

Pizzigoni, C., The Life Within: Local Indigenous Society in Mexico's Toluca Valley, 16501800, Stanford, Stanford University Press, 2012.

Poole, S., Pedro Moya de Contreras: Catholic Reform and Royal Power in New Spain, 1571-1591, Norman, University of Oklahoma Press, 2011.

- Juan de Ovando: Governing the Spanish Empire in the Reign of Philip II, Norman, University of Oklahoma Press, 2004.

- Our Lady of Guadalupe: The Origins and Sources of a Mexican National Symbol, 15311797, Tucson, University of Arizona Press, 2017.

Premo, B., The Enlightenment on Trial: Ordinary Litigants and Colonialism in the Spanish Empire, New York, Oxford University Press, 2017.

Radding, C., Landscapes of Power and Identity: Comparative Histories in the Sonoran Desert and the Forests of Amazonia from Colony to Republic, Durham, Duke University Press, 2005.

Ramírez, P., Enlightened Immunity: Mexico's Experiments with Disease Prevention in the Age of Reason, Stanford, Stanford University Press, 2018.

Ramírez, S. E., To Feed and Be Fed: The Cosmological Bases of Authority and Identity in the Andes, Stanford, Stanford University Press, 2005.

- The World Upside Down: Cross-cultural Contact and Conflict in Sixteenth-Century Peru, Stanford, Stanford University Press, 1996.

- Provincial Patriarchs: Land Tenure and the Economics of Power in Colonial Peru, Albuquerque, University of New Mexico Press, 1986.

Ramos, F., Identity, Ritual, and Power in Colonial Puebla, Tucson, University of Arizona Press, 2012.

Ramos, G., Death and Conversion in the Andes: Lima and Cuzco, 1532-1670, South Bend, Notre Dame University Press, 2010.

Rausch, J., Tropical Plains Frontier: The Llanos of Colombia, 1531-1831, Albuquerque, University of New Mexico Press, 1984.

Reséndez, A., The Other Slavery: The Uncovered Story of Indian Enslavement in America, Boston, Houghton Mifflin, 2016.

Restall, M., When Montezuma Met Cortés: The True Story of the Meeting that Changed 
History, New York, Ecco, 2018.

- The Black Middle: Africans, Mayas, and Spaniards in Colonial Yucatan, Stanford, Stanford University Press, 2009.

- Seven Myths of the Spanish Conquest, New York, Oxford University Press, 2003.

- Maya Conquistador, Boston, Beacon, 1998.

- The Maya World: Yucatec Culture and Society, 1550-1850, Stanford, Stanford University Press, 1997.

Rodríguez Ordóñez, J. E., Political Culture in Spanish America, 1500-1830, Lincoln, University of Nebraska Press, 2017.

- "We Are Now the True Spaniards": Sovereignty, Revolution, Independence, and the Emergence of the Federal Republic of Mexico, 1808-1824, Stanford, Stanford University Press, 2012.

Salomon, F. and Urioste, G. (eds. and trans.), The Huarochirí Manuscript: A Testament of Ancient and Colonial Andean Religion, Austin, University of Texas Press, 1991.

Salomon, F., Native Lords of Quito in the Age of the Incas: The Political Economy of NorthAndean Chiefdoms, Cambridge, Cambridge University Press, 1986.

Sarreal, J., The Guaraní and their Missions: A Socioeconomic History, Stanford, Stanford University Press, 2014.

Schmidt-Nowara, C., "Spanish Origins of the American Empire: Hispanism, History, and Commemoration, 1898-1915", International History Review, 30:1 (Mar. 2008), pp. 3251.

- The Conquest of History: Spanish Colonialism and National Histories in the Nineteenth Century, Pittsburgh, Pittsburgh University Press, 2006.

Schroeder, S. and Poole, S. (eds.), Religion in New Spain, Albuquerque, University of New Mexico Press, 2007.

Schroeder, S., Wood, S. and Haskett, R. (eds.), Indian Women of Early Mexico, Norman, University of Oklahoma Press, 1997.

Schwaller, J. F., The Fifteenth Month: Aztec History in the Rituals of Panquetzaliztli, Norman, University of Oklahoma Press, 2019.

- The First Letter from New Spain: The Lost Petition of Cortés and his Company, June 20, 1519, Austin, University of Texas Press, 2014.

- The Church and Clergy in Sixteenth-Century Mexico, Albuquerque, University of New Mexico Press, 1987.

Schwaller, J. F. (ed.), The Church in Colonial Latin America, Wilmington, DE, Scholarly Resources, 2000.

Schwaller, R. C., Géneros de Gente in Early Colonial Mexico, Norman, University of Oklahoma Press, 2016.

Schwartz, S. B., Sea of Storms: A History of Hurricanes in the Greater Caribbean from Columbus to Katrina, Princeton, Princeton University Press, 2015.

- All Can Be Saved: Religious Tolerance and Salvation in the Iberian Atlantic World, New Haven, Yale University Press, 2008.

Schwartz, S. B. (ed.), Tropical Babylons: Sugar and the Making of the Atlantic World, 14501680, Chapel Hill, University of North Carolina Press, 2004.

- Implicit Understandings: Observing, Reporting, and Reflecting on the Encounters between Europeans and other Peoples in the Early Modern Era, New York, Cambridge University Press, 1994.

Sellers-García, S., The Woman on the Windowsill: A Tale of Mystery in Several Parts, New Haven, Yale University Press, 2020.

- Distance and Documents at the Spanish Empire's Periphery, Stanford, Stanford California 
Press, 2014

Sharp, W. F., Slavery on the Spanish Frontier: The Colombian Chocó, 1680-1810, Norman, University of Oklahoma Press, 1976.

Sierra Silva, P. M., Urban Slavery in Colonial Mexico: Puebla de los Ángeles, 1531-1706,

New York, Cambridge University Press, 2018.

Silverblatt, I., Modern Inquisitions: Peru and the Colonial Origins of the Civilized World, Durham, Duke University Press, 2004.

- Moon, Sun, and Witches: Gender Ideologies and Class in Inca and Colonial Peru, Princeton, Princeton University Press, 1987.

Skopyk, B., Colonial Cataclysms: Climate, Landscape, and Memory in Mexico's Little Ice Age, Tucson, University of Arizona Press, 2020.

Sluiter, E., Gold and Silver of Spanish America, c.1572-1648, Berkeley, Bancroft Library, 1998.

Socolow, S., The Women of Colonial Latin America, New York, Cambridge University Press, 2015.

- The Bureaucrats of Buenos Aires, 1769-1810. Amor al Real Servicio, Durham, Duke University Press, 1987.

- The Merchants of Buenos Aires, 1778-1810, Cambridge, Cambridge University Press, 1978.

Solari, A., Maya Ideologies of the Sacred: The Transfiguration of Space in Colonial Yucatan, Austin, University of Texas Press, 2013.

Sousa, L., The Woman Who Turned Into a Jaguar and Other Narratives of Native Women in the Archives of Colonial Mexico, Stanford, Stanford University Press, 2017.

Stavig, W., The World of Túpac Amaru: Conflict, Community, and Identity in Colonial Peru, Lincoln, University of Nebraska Press, 1999.

Stein, B. H. and Stein, S. J., Crisis in an Atlantic Empire and New Spain, 1808-1810, Baltimore, Johns Hopkins University Press, 2014.

- Edge of Crisis: War and Trade in the Spanish Atlantic, 1789-1808, Baltimore, Johns Hopkins University Press, 2009.

Stein, S. J. and Stein, B. H., Apogee of Empire: Spain and New Spain in the Age of Charles III, 1759-1789, Baltimore, Johns Hopkins University Press, 2003.

- The Colonial Heritage of Latin America: Essays on Economic Dependence in Perspective, New York, Oxford University Press, 1970.

Stern, S. J., The Secret History of Gender. Women, Men, and Power in Late Colonial Mexico, Chapel Hill, University of North Carolina Press, 1995.

- Peru's Indian Peoples and the Challenge of Spanish Conquest: Huamanga to 1640, Madison, University of Wisconsin Press, 1982.

Taylor, W. B., Theater of A Thousand Wonders: A History of Miraculous Images and Shrines in New Spain, New York, Cambridge University Press, 2016.

- Magistrates of the Sacred: Priests and Parishioners in Eighteenth-Century Mexico, Stanford, Stanford University Press, 1996.

- Drinking, Homicide, and Rebellion in Colonial Mexican Villages, Stanford, Stanford University Press, 1979.

- Landlord and Peasant in Colonial Oaxaca, Stanford, Stanford University Press, 1972.

TePaske, J. J. and Brown, K., A New World of Gold and Silver, Leiden, Brill, 2010.

Terraciano, K., The Mixtecs of Colonial Oaxaca: Nudzahui History, Sixteenth through Eighteenth Centuries, Stanford, Stanford University Press, 2001.

Thomson, S., We Alone Will Rule: Native Andean Politics in the Age of Insurgency, Madison, University of Wisconsin Press, 2002. 
Tortorici, Z., Sins Against Nature: Sex and Archives in Colonial New Spain, Durham, Duke University Press, 2018.

Townsend, C., Annals of Native America: How the Nahuas of Colonial Mexico Kept their History Alive, New York, Oxford University Press, 2017.

- Malintzin's Choices: An Indian Woman in the Conquest of Mexico, Albuquerque, University of New Mexico Press, 2006.

Tutino, J., Making a New World: Founding Capitalism in the Bajío and Spanish North America, Durham, Duke University Press, 2011.

Twinam. A., Purchasing Whiteness: Pardos, Mulattos, and the Quest for Social Mobility in the Spanish Indies, Stanford, Stanford University Press, 2015.

- Public Lives, Private Secrets: Gender, Honor, Sexuality, and Illegitimacy in colonial Spanish America, Stanford, Stanford University Press, 1999.

- Miners, Merchants, and Farmers in Colonial Colombia, Austin, University of Texas Press, 1982.

Van Young, E., The Other Rebellion: Popular Violence, Ideology, and the Mexican Struggle for Independence, 1810-1821, Stanford, Stanford University Press, 2001.

- Hacienda and Market in Eighteenth-Century Mexico: The Rural Economy of the Guadalajara Region, 1675-1820, Berkeley, University of California Press, 1981.

Vilches, E., New World Gold: Cultural Anxiety and Monetary Disorder in Early Modern Spain, Chicago, University of Chicago Press, 2010.

Villella, P. B., Indigenous Elites and Creole Identity in Colonial Mexico, 1500-1800, New York, Cambridge University Press, 2016.

Vinson, B., Before Mestizaje: The Frontiers of Race and Caste in Colonial Mexico, New York, Cambridge University Press, 2018.

- Bearing Arms for His Majesty: The Free-Colored Militia in Colonial Mexico, Stanford, CA: Stanford University Press, 2001.

Voigt, L., Spectacular Wealth: The Festivals of Colonial South American Mining Towns, Austin, University of Texas Press, 2016.

- Writing Captivity in the Early Modern Atlantic: Circulations of Knowledge and Authority in the Iberian and English Imperial Worlds, Chapel Hill, University of North Carolina Press, 2009.

Walker, C. F., The Tupac Amaru Rebellion, Cambridge, MA, Belknap, 2016.

- Shaky Colonialism: The 1746 Earthquake-Tsunami in Lima, Peru, and its Long Aftermath, Durham, Duke University Press, 2008.

Ward, C., Imperial Panama: Commerce and Conflict in Isthmian America, 1550-1800, Albuquerque, University of New Mexico Press, 1993.

Warren, A., Medicine and Politics in Colonial Peru: Population Growth and the Bourbon Reforms, Pittsburgh, University of Pittsburgh Press, 2010.

Warsh, M., American Baroque: Pearls and the Nature of Empire, 1492-1700, Chapel Hill, University of North Carolina Press, 2018.

Weber, D. J., Bárbaros: Spaniards and their Savages in the Age of Enlightenment, New Haven, Yale University Press, 2005.

Weber, D. J. and Rausch, J. (eds.), Where Cultures Meet: Frontiers in Latin American History, Wilmington, DE, SR Books, 1994.

Webster, S. V., Lettered Artists and the Languages of Empire: Painters and the Profession in Early Colonial Quito, Austin, University of Texas Press, 2017.

Wey-Gómez, N., Tropics of Empire: Why Columbus Sailed South to the Indies, Cambridge, MA, MIT Press, 2008.

Wood, S., Transcending Conquest: Nahua Views of Spanish Colonial Mexico, Norman, 
University of Oklahoma Press, 2003.

Yannakakis, Y. and Ramos, G. (eds.), Indigenous Intellectuals: Knowledge, Power, and Colonial Culture in Mexico and the Andes, Durham, Duke University Press, 2014.

Yannakakis, Y., The Art of Being In-Between: Native Intermediaries, Indian Identity, and Local Rule in Colonial Oaxaca, Durham, Duke University Press, 2008. 